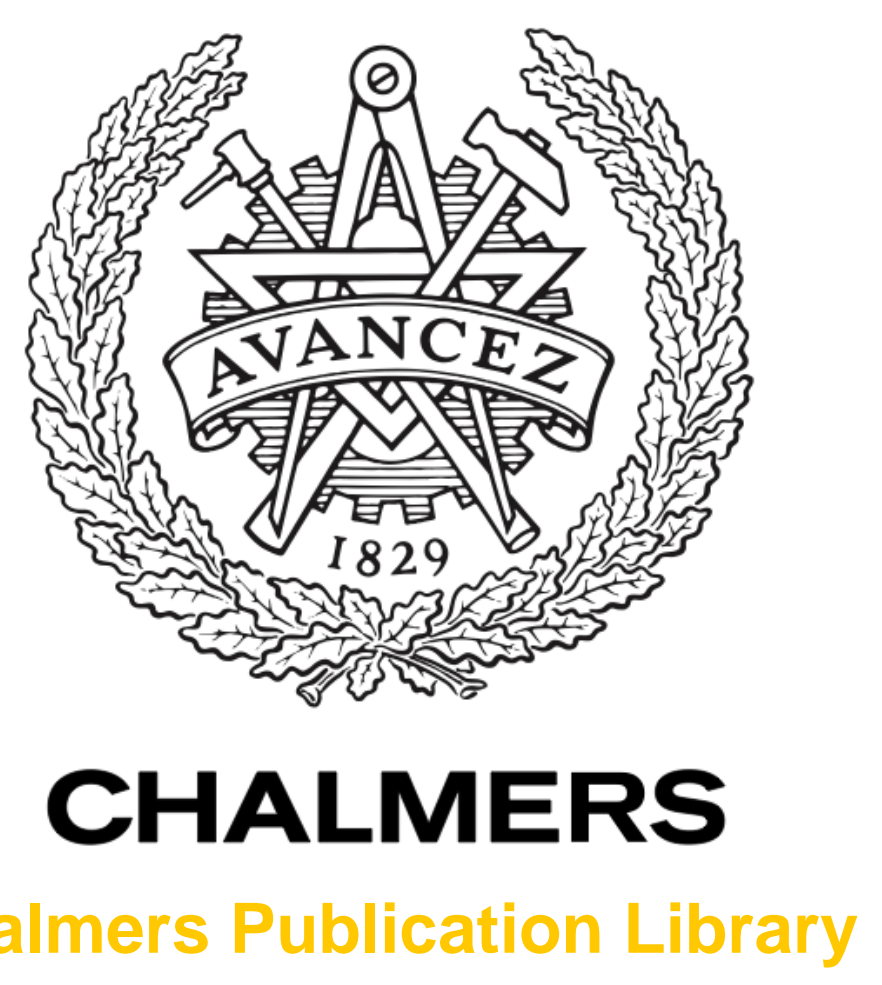

Challmers Publication Library

\title{
Comparison of large- and small-scale circulating fluidized bed combustors with respect to pollutant formation and reduction for different fuels
}

This document has been downloaded from Chalmers Publication Library (CPL). It is the author's version of a work that was accepted for publication in:

Fuel

Citation for the published paper:

Knöbig, T. ; Werther, J. ; Åmand, L. et al. (1998) "Comparison of large- and small-scale circulating fluidized bed combustors with respect to pollutant formation and reduction for different fuels". Fuel, vol. 77 pp. 1635-1642.

Downloaded from: http://publications.lib.chalmers.se/publication/4964

Notice: Changes introduced as a result of publishing processes such as copy-editing and formatting may not be reflected in this document. For a definitive version of this work, please refer to the published source. Please note that access to the published version might require a subscription. 


\title{
Comparison of large- and small-scale circulating fluidized bed combustors with respect to pollutant formation and reduction for different fuels
}

\author{
T. Knöbig ${ }^{a}$, J. Werther ${ }^{a, *}$, L.-E. Åmand ${ }^{b}$ and B. Leckner ${ }^{b}$ \\ ${ }^{a}$ Technical University Hamburg-Harburg, Chemical Engineering I, Denickestrasse 15, \\ 21071 Hamburg, Germany \\ ${ }^{\mathrm{b}}$ Chalmers University of Technology, Department of Energy Conversion, Goeteborg, Sweden \\ (Received 15 November 1997; accepted 27 May 1998)
}

\begin{abstract}
To investigate the scale-up problem of circulating fluidized bed combustors with particular respect to emissions, comparative combustion experiments have been performed in an industrial-size combustor (12 $\mathrm{MW}_{\text {th }}$, height $14 \mathrm{~m}$, cross-sectional area $1.6 \mathrm{~m} \times 1.6 \mathrm{~m}$ ) and in a lab-scale facility (height $16 \mathrm{~m}$, inner diameter $100 \mathrm{~mm}$ ). A comparison of the axial concentration profiles of oxygen, carbon monoxide, nitric oxide, nitrous oxide and ammonia along the riser height, obtained during the combustion of wood, peat and coal under conditions of equal fuel bed material, solid holdup and gas residence time, shows a basic similarity. This indicates that suitably sized and operated lab-scale combustors may indeed be valuable tools for the investigation of combustion phenomena. However, some significant deviations of the profiles can be recognized, too. These deviations are caused by threedimensional effects in the large-scale combustor and indicate the limitations of small-scale experiments. (C) 1998 Elsevier Science Ltd. All rights reserved
\end{abstract}

(Keywords: circulating fluidized bed combustors; scale-up; pollutant formation)

\section{INTRODUCTION}

Laboratory- and pilot-scale combustors with circulating fluidized beds (CFB) have played a prominent role in understanding the phenomena involved in the combustion process, thus avoiding a repetition of some spectacular scale-up failures of the past ${ }^{1}$. Such scale-up studies are even more justified at present considering the high costs for fullscale experimental studies. As a consequence of the complexity of the combustion process and its underlying flow structure, the combustion and emission behaviour of large-scale boilers with circulating fluidized beds is not yet fully understood ${ }^{2}$. Since the combustion chambers of largescale boilers are difficult to access, research groups perform experiments in small-scale experimental facilities to investigate the combustion behaviour. Small-scale experimental CFB combustors are useful research tools ${ }^{3}$, because they are easy to operate at a comparatively low cost. They can quickly be modified for special investigations and can be used for the characterization of new fuels because of their fuel flexibility ${ }^{4,5}$. Regarding the different geometries of large-scale and small-scale facilities, it is obvious that a scale-up problem exists ${ }^{2}$ : How can the results from experiments in small-scale units be translated to conditions in large-scale boilers?

\footnotetext{
* To whom correspondence should be addressed
}

Small-scale combustors differ from full-scale facilities in several ways. The height of the test facility, which is normally smaller than the height of the large-scale combustor, reduces the gas residence time. The smaller diameter of the small-scale vessel ensures better radial mixing of the fuel and of the secondary air. In the case of circulating fluidized bed combustion, a smaller cyclone of the test facility improves the collection of finer size particles which are recycled back to the combustion chamber ${ }^{3}$. Three-dimensional effects in large-scale boilers, caused by feed points, solid returns and secondary-air injections, lead to an uneven distribution of the gaseous compounds inside the combustion chamber, and cannot readily be simulated in small-scale units ${ }^{6}$. Therefore, considering some obvious limitations, it is necessary to know in which way tests in small-scale combustors should be conducted to transfer the results to full-scale boilers.

A widely accepted scale-up method in the engineering sciences is the use of scaling laws. These consist of dimensionless quantities which allow the transfer of results from a small-scale combustor to a full-scale facility. The problem is to know the correct scaling laws for the problem under investigation.

Scaling laws for hydrodynamic similarity of circulating fluidized beds have been formulated by Glicksman et $a l^{7}$ and Horio et al. ${ }^{8}$. Glicksman et al. established a set of 
eight scaling parameters:

$$
\begin{aligned}
& \frac{\rho_{\mathrm{g}} \cdot u \cdot L}{\mu}, \frac{\rho_{\mathrm{g}} \cdot u \cdot d_{\mathrm{p}}}{\mu}, \frac{g \cdot L}{u^{2}}, \frac{\rho_{\mathrm{g}}}{\rho_{\mathrm{p}}}, \frac{L_{1}}{L_{2}}, \frac{G_{\mathrm{s}}}{\rho_{\mathrm{p}} \cdot u}, \Phi, \\
& \text { particle }- \text { size distribution }
\end{aligned}
$$

The first parameter is a Reynolds number based on the characteristic length of the fluidized bed, and the second parameter is a Reynolds number based on the particle diameter. The third parameter is the Froude number based on a characteristic length of the bed. Furthermore, there are the density ratio of gas to solids and the ratio of two characteristic lengths of the bed. In the case of circulating fluidized beds, the dimensionless net flux of solids is taken into consideration as a further parameter. The last two parameters are the sphericity $(\Phi)$ of the particles and the particle-size distribution. With this set of parameters, good agreement between the axial solids distributions in a fullscale combustor and a small-scale unit was obtained 9 .

The scaling laws of Glicksman et al. and those of Horio et al. consider the fluid dynamics and do not take chemical reactions into account. Hydrodynamical similarity, however, may not be sufficient to allow the transfer of results from small-scale combustion experiments to a large boiler. The necessary 'chemical' similarity should consider additional effects, such as mixing of gas and solids and gas/solid contact $^{10}$.

The present paper deals with the general question of whether combustion experiments in a small- or laboratoryscale facility can be carried out in such a way that they are representative of large-scale boilers. For this purpose, comparative combustion experiments were performed in an industrial-size combustor at Chalmers University of Technology and in a bench-scale facility at the Technical University Hamburg-Harburg.

\section{THEORY}

To simulate the combustion and emission behaviour of fullscale combustors in pilot plants, it is necessary to adopt the operational conditions of the large facility as far as possible. Lundqvist et al. ${ }^{1}$ performed comparative combustion experiments in a $110 \mathrm{MW}_{\mathrm{e}}$ commercial CFB boiler and in a $0.6 \mathrm{MW}_{\text {th }}$ pilot plant. They varied a number of process parameters during combustion of the same coals in order to investigate their influence on boiler performance. To reach similar conditions in both units, they adjusted the operational parameters to get similar boiler loads, similar bed temperatures, the same oxygen in the flue gas and the same ratio of primary fluidizing air to total air. With this set of parameters, however, both the superficial gas velocity and the gas residence time were different in the two units. This set of parameters resulted in lower $\mathrm{NO}$ and higher $\mathrm{CO}$ emission values for the pilot-scale combustor compared with the large-scale plant, but both units showed a general trend of NO increasing with temperature.

As minimum conditions for hydrodynamic similarity, it is suggested here to use the same bed material and the same fluidization velocity in the small unit and in the large boiler. As minimum conditions to meet chemical similarity, the same gas residence time and the same solid holdup should be applied and the same fuels should be used in both units. The criterion of the same gas residence times for similar emission values was also reported by Katayama et al. ${ }^{11}$. They compared a bench-scale vessel $\left(0.25 \mathrm{~m}^{2}\right.$ crosssectional area) and a commercial stationary fluidized bed boiler $\left(9.43 \mathrm{~m}^{2}\right.$ cross-sectional area) and found that the conversion of nitrogen in the fuel to NO was the same for the same gas residence time. In addition, they showed similar tendencies for both units for variations in gas residence time.

Since the two facilities investigated differ in height, total similarity could be not be achieved in the present case: it was not possible to adapt both gas residence time and fluidization velocity. Thus it was decided to use the same gas residence time and to allow the fluidization velocity to be different. The average gas residence time can be written in terms of the superficial gas velocity and the height of the combustion chamber according to

$$
\frac{H_{\mathrm{TUHH}}}{u_{\mathrm{TUHH}}}=\frac{H_{\mathrm{CTH}}}{u_{\mathrm{CTH}}}
$$

where the subscript CTH denotes the commercial boiler of Chalmers University of Technology and TUHH the experimental unit at the Technical University Hamburg-Harburg. Transforming eqn (2), one obtains

$$
u_{\mathrm{TUHH}}=\frac{H_{\mathrm{TUHH}}}{H_{\mathrm{CTH}}} \cdot u_{\mathrm{CTH}}
$$

The requirement of equal solids holdup means

$$
\bar{c}_{\mathrm{v} \text {, mean, TUHH }}=\bar{c}_{\mathrm{v} \text {, mean, } \mathrm{CTH}}
$$

The average solids concentration in the combustion chamber, $\bar{c}_{\mathrm{v} \text {, mean }}$, is related to the pressure drop in the combustion chamber

$$
\Delta p=\rho_{\mathrm{p}} \cdot g \cdot H \cdot \bar{c}_{\mathrm{v}, \text { mean }}
$$

Substituting $\bar{c}_{\mathrm{v} \text {, mean }}$ in eqn (4) by the pressure drop in the riser yields

$$
\frac{\Delta p_{\mathrm{TUHH}}}{\rho_{\mathrm{p}, \mathrm{TUHH}} \cdot g \cdot H_{\mathrm{TUHH}}}=\frac{\Delta p_{\mathrm{CTH}}}{\rho_{\mathrm{p}, \mathrm{CTH}} \cdot g \cdot H_{\mathrm{CTH}}}
$$

Since the solid density of the bed material is the same in both combustors, the pressure drop in the experimental vessel $\left(\Delta p_{\mathrm{TUHH}}\right)$ should be

$$
\Delta p_{\mathrm{TUHH}}=\frac{H_{\mathrm{TUHH}}}{H_{\mathrm{CTH}}} \cdot \Delta p_{\mathrm{CTH}}
$$

With the criterion of having the same gas residence time and with the same solid holdup, similarity as far as possible is achieved in the vertical direction. However, there is no geometrical similarity in the horizontal direction, because the cross-sections of the combustors are different. There is no operating parameter that could be varied in order to obtain similarity in the horizontal direction as well. One task of the present study is therefore to reveal whether or not horizontal profiles in the combustion chamber play an important role.

\section{EXPERIMENTAL}

\section{The combustors}

For comparison, the geometries of the combustors investigated are shown in Figure 1. The basic idea of the rather slim and tall geometry of the test facility in Harburg is to obtain as much hydrodynamic and chemical similarity with large-scale combustors as possible. Also, the position of the secondary-air injection was chosen according to the full-scale facility, since the emissions of $\mathrm{CO}, \mathrm{NO}_{x}$ and $\mathrm{N}_{2} \mathrm{O}$ in particular depend strongly on the location of the seondary-air injection ${ }^{12}$. Table 1 gives an overview of the 


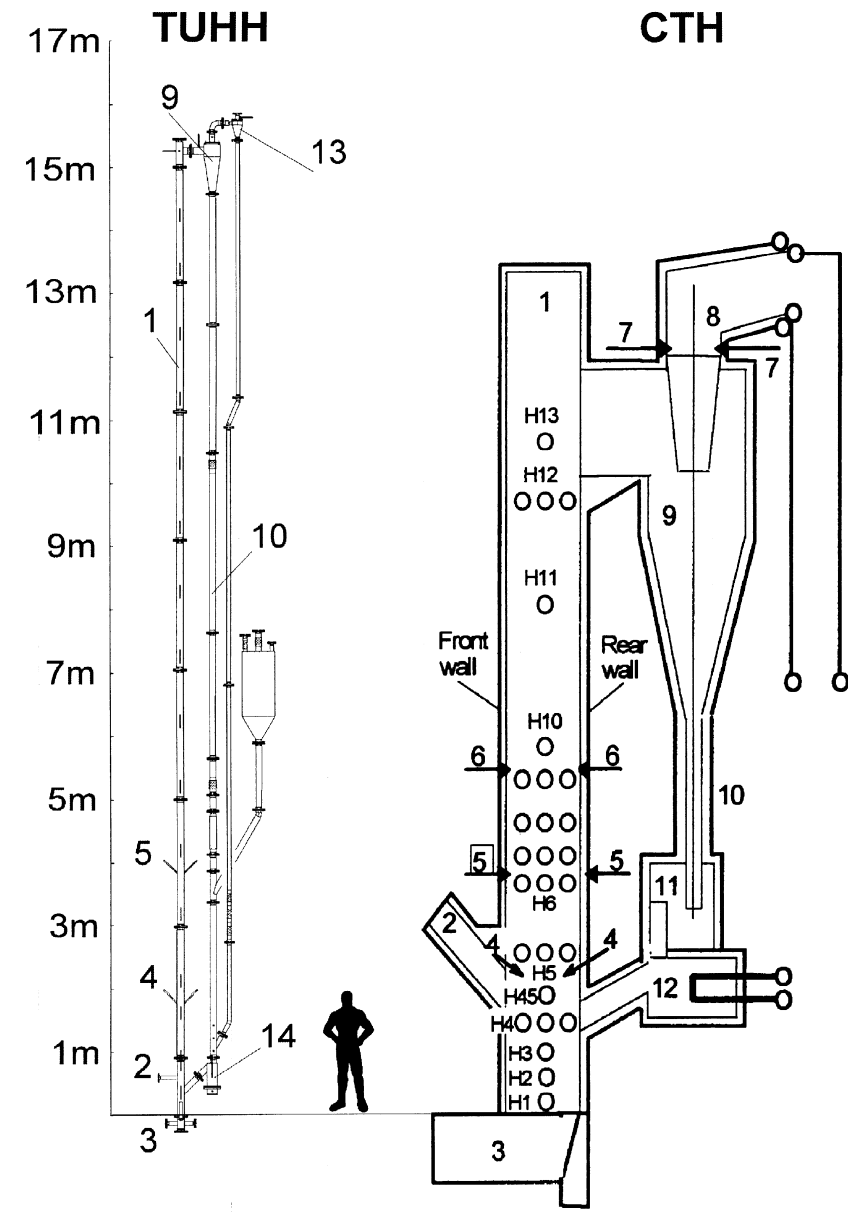

Figure 1 Comparison of the geometries of the combustors at TUUH (height: $15.5 \mathrm{~m}$, inner diameter: $100 \mathrm{~mm}$ ) and CTH $\left(12 \mathrm{Mw}_{\text {th }}\right.$, height: $13.5 \mathrm{~m}$, cross-sectional area: $\left.1.6 \mathrm{~m} \times 1.6 \mathrm{~m}\right)$ : 1 -combustion chamber, 2-fuel feed chute, 3-air plenum, 4, 5, 6, 7-secondary-air inlets, 8-cyclone exit duct, 9-primary cyclone, 10-particle return leg, 11-particle seal, 12-heat exchanger, 13-secondary cyclone, 14-syphon

Table 1 Operating conditions and geometry data for the combustors

\begin{tabular}{lll}
\hline & TUHH & CTH \\
\hline Height of combustion chamber $(\mathrm{m})$ & 15.5 & 13.5 \\
Height until middle of cyclone inlet $(\mathrm{m})$ & 15.2 & 11 \\
$\begin{array}{l}\text { Height until secondary }- \text { air injection } \\
\text { Height until middle of cyclone inlet }\end{array}$ & 0.23 & 0.2 \\
Cross-section of combustion chamber & circular & square \\
& $0.1 \mathrm{~m} \mathrm{i.d.}$ & $1.6 \mathrm{~m} \times 1.6 \mathrm{~m}$ \\
$\begin{array}{l}\text { Superficial gas velocity after secondary-air } \\
\text { injection }\left(\mathrm{m} \mathrm{s}^{-1}\right)\end{array}$ & 7 & 6 \\
$\Delta p_{\text {riser }}(\mathrm{MPa})$ & 7 & 6 \\
Excess air ratio & 1.2 & 1.2 \\
Primary/total air & 0.58 & 0.58 \\
$T\left({ }^{\circ} \mathrm{C}\right)$ & 850 & 850 \\
\hline
\end{tabular}

operating conditions and geometry data of the combustors.

Since the test runs were performed with staged combustion, a stoichiometric ratio in the bottom part of the bed of $\lambda_{\text {bed }}=0.7$ and an overall excess air ratio for the whole combustor of $\lambda=1.2$ were chosen. This means an oxygen concentration in the flue gas of $3.5 \mathrm{vol} \%$ (dry basis).

In both combustors, gas samples are withdrawn at various points along the riser height and sucked with a gas pump through heated sampling lines to the analysers for $\mathrm{O}_{2}, \mathrm{CO}_{2}$, $\mathrm{CO}, \mathrm{NO}, \mathrm{N}_{2} \mathrm{O}$ and $\mathrm{NH}_{3}$. For more details about the measuring systems, see Werther et al. ${ }^{13}$ and Åmand et al. ${ }^{14}$.

To obtain similar combustion and emission behaviour, the temperature in both combustors was maintained at $850^{\circ} \mathrm{C}$. To compensate for heat losses caused by the relatively large surface-to-volume ratio of the TUHH unit, its riser and its downcomer are completely surrounded by electrical heating elements. The CFB combustor of $\mathrm{CTH}$ is designed in the form of a commercial boiler with two membrane tube walls, two refractory-lined walls and a heat exchanger in the solid return line to control the combustion temperature.

\section{The fuels}

Three different kinds of fuel were investigated: coal, peat and wood. The proximate and ultimate analyses can be seen in Tables 2 and 3, respectively. Wood contains the highest amount of volatiles among the fuels, but almost no ash. The nitrogen content is of special interest for the formation of $\mathrm{NO}$ or $\mathrm{N}_{2} \mathrm{O}$. This content is low for wood. Coal contains only a small amount of oxygen, but peat and wood have comparably high oxygen contents. Coal has the highest amount of carbon in comparison with wood and peat.

The peat was fed into the CTH combustor in the form of cylindrical briquettes with a diameter of about $0.07 \mathrm{~m}$ and varying length of about $0.05-0.1 \mathrm{~m}$. The particle-size distribution of the wood and coal used at Chalmers can be seen in Figure 2. The mean diameter of the fuel particles and the fuel particle-size distribution should be kept the same in the pilot and in the commercial plant. Otherwise, the combustion behaviour can change drastically ${ }^{5}$. Since the combustor at TUHH has a very small diameter compared with the Chalmers boiler, it was not possible to feed the fuels, as they were used at CTH, into the TUHH facility and a comminution was necessary to obtain a suitable particlesize distribution of the feed for the TUHH combustor.

To minimize the effect of the reduction in particle size of the fuels on the desired chemical similarity, the reduction ratio was kept as low as possible. Figure 3 shows the particle-size distributions of the fuels after milling and sieving. It should be noted that the particle sizes of the inlet fuel, depicted in Figures 2 and 3, are different from the fuel particle size in the bed, because of fragmentation and attrition $^{15}$. Other investigators have also had to face the

Table 2 Proximate analysis of the fuels investigated

\begin{tabular}{lccc}
\hline & Coal & Peat & Wood \\
\hline Water (wt\%, raw) & 7.5 & 37 & $10.1^{a}$ \\
Ash (wt\%, maf) & 5.3 & 6.8 & 0.9 \\
C fixed (wt\%, maf) & 61 & 30.2 & 22 \\
Volatiles (wt\%, maf) & 39 & 69.8 & 78 \\
\hline
\end{tabular}

${ }^{a}$ The wood was predried

Table 3 Ultimate analysis of the fuels investigated

\begin{tabular}{lccc}
\hline & Coal & Peat & Wood \\
\hline C (wt\%, maf) & 88.0 & 57.1 & 50.7 \\
H (wt\%, maf) & 6.0 & 6.3 & 5.9 \\
O (wt\%, maf) & 4.0 & 33.5 & 43.1 \\
N (wt\%, maf) & 1.2 & 23 & 0.2 \\
S (wt\%, maf) & 0.8 & 0.8 & 0.04 \\
\hline
\end{tabular}




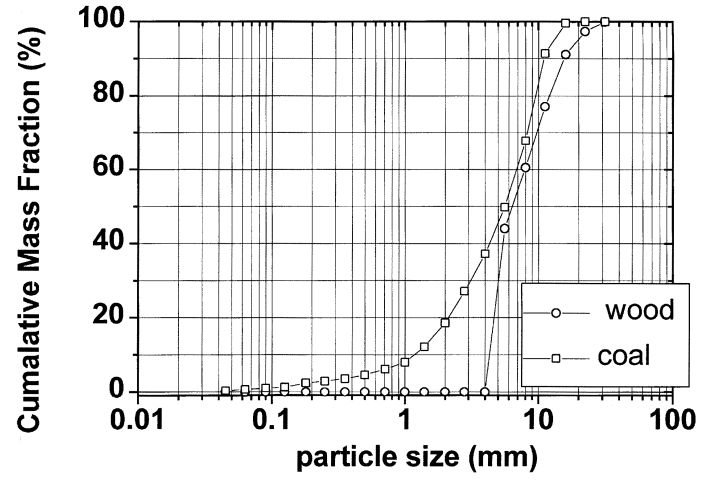

Figure 2 Particle-size distribution of coal and wood used at Chalmers

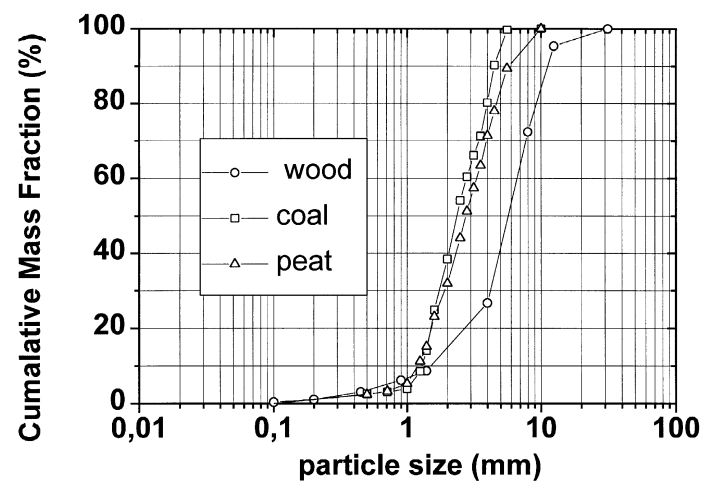

Figure 3 Particle-size distribution of fuels used at TUHH, after comminution and sieving

problem of different fuel and ash particle-size distributions in large-scale and pilot-scale combustors. Lundqvist et al. ${ }^{1}$ reported feed particle sizes between 1 to $4 \mathrm{~mm}$ and 0.2 to $1.2 \mathrm{~mm}$ for the commercial combustor and the pilot-scale vessel, respectively. Despite these differences in ash discharge and fuel size, they observed a similar ratio of bottom to total ash, indicating that the scale-up effect had only a minor influence on the vertical solids distribution in that particular case.

\section{The bed materials}

To obtain fluid dynamical similarity, it is necessary to use the same bed material in both combustors. Furthermore, the bed material has an influence on the chemical similarity, because some of the formation and reduction reactions of $\mathrm{NO}_{x}$ and $\mathrm{N}_{2} \mathrm{O}$ are catalysed by the bed material ${ }^{16}$. Since the compositions of the fuel ashes are different during combustion of each fuel, the bed materials of coal, peat and wood combustion were withdrawn at the CTH boiler and thereafter used for the experiments at TUHH. Table 4 shows the compositions of the bed materials of coal, peat and wood combustion.

\section{RESULTS AND DISCUSSION}

In the following section the combustors are compared by plotting the axial profiles of the measured gaseous species inside the combustion chambers during coal, peat and wood combustion in pairs of diagrams (Figures 4-9). Each upper diagram shows the profiles in the Chalmers boiler, whereas in the lower diagram the profiles of the TUHH test rig are depicted.

Figure 4 shows the axial oxygen concentration profiles. In the bottom part of the bed the oxygen consumption is very strong and the oxygen concentrations inside both combustors decrease rapidly. Thereafter the secondary air causes an increase of the concentrations, which seems to be much stronger in the TUHH combustor.

This impression changes when the fact is considered that the CTH concentration profiles in Figure 4 represent gas samples, which were withdrawn on the centreline of the combustion chamber of CTH. Figure 5 shows additional axial profiles which were taken at distances of $0.37 \mathrm{~m}$ from the front and the rear walls, where the inlets of the secondary air are located. Obviously, penetration of the secondary air is incomplete, and an increase of the oxygen concentration at the injection level is only recognized in the vicinity of the walls and not in the centre of the combustion chamber. This uneven lateral distribution over the crosssection is a typical large-scale three-dimensional effect. It does not occur in the TUHH combustor, where the secondary air can be considered to be mixed almost immediately with the main gas stream over the crosssectional area, owing to the slim and tall geometry of the riser. Since the extension of the gas-sampling probe inside the combustion chamber of TUHH reaches over the whole diameter, it may be concluded that the concentration values inside the TUHH riser are roughly cross-sectional averages, whereas in the CTH combustion chamber only local concentration measurements are made. By using smaller gas-sampling probes, which allow local gas concentration measurements in small-scale units, Gohla et al. ${ }^{17}$ measured radial profiles of $\mathrm{O}_{2}, \mathrm{NO}$ and $\mathrm{CO}$ inside two lab-scale CFB combustors with inner diameters of $53 \mathrm{~mm}$ and $96 \mathrm{~mm}$. Despite their small diameter, the two-lab scale facilities showed a significantly uneven distribution of the measured gas species over the cross-section, caused by combustion of volatiles in the vicinity of the feed point. The experiments of Gohla were conducted without staged combustion, thus no statement concerning secondary-air mixing was made in their work.

The lowest oxygen concentrations are found in both combustors below the secondary-air injection in the bottom part of the riser during coal combustion. This is caused by the reducing conditions in the bottom section yielding high values of $\mathrm{CO}$ concentration (Figure 6). Both combustors have their maximum $\mathrm{CO}$ values for the three fuels in the bottom section, but the $\mathrm{CO}$ concentrations are much higher in the larger combustor.

Since the fuel particles in the bottom region of the Chalmers boiler are coarser than in the TUHH facility, a

Table 4 Bed material compositions (wt\%) from coal, peat and wood combustion

\begin{tabular}{lcccccccc}
\hline & $\mathrm{SiO}_{2}$ & $\mathrm{Fe}_{2} \mathrm{O}_{3}$ & $\mathrm{Al}_{2} \mathrm{O}_{3}$ & $\mathrm{CaO}$ & $\mathrm{MgO}$ & $\mathrm{Na}_{2} \mathrm{O}$ & $\mathrm{K}_{2} \mathrm{O}$ \\
\hline Coal & 20.9 & 7.2 & 7.1 & 32.1 & 1.0 & 0.6 & 0.9 & 0.1 \\
Peat & 24.6 & 8.2 & 8.1 & 31.7 & 1.2 & 0.6 & 0.4 \\
Wood & 12.8 & 5.2 & 4.1 & 45.2 & 0.9 & 0.6 & 0.5 \\
\hline
\end{tabular}



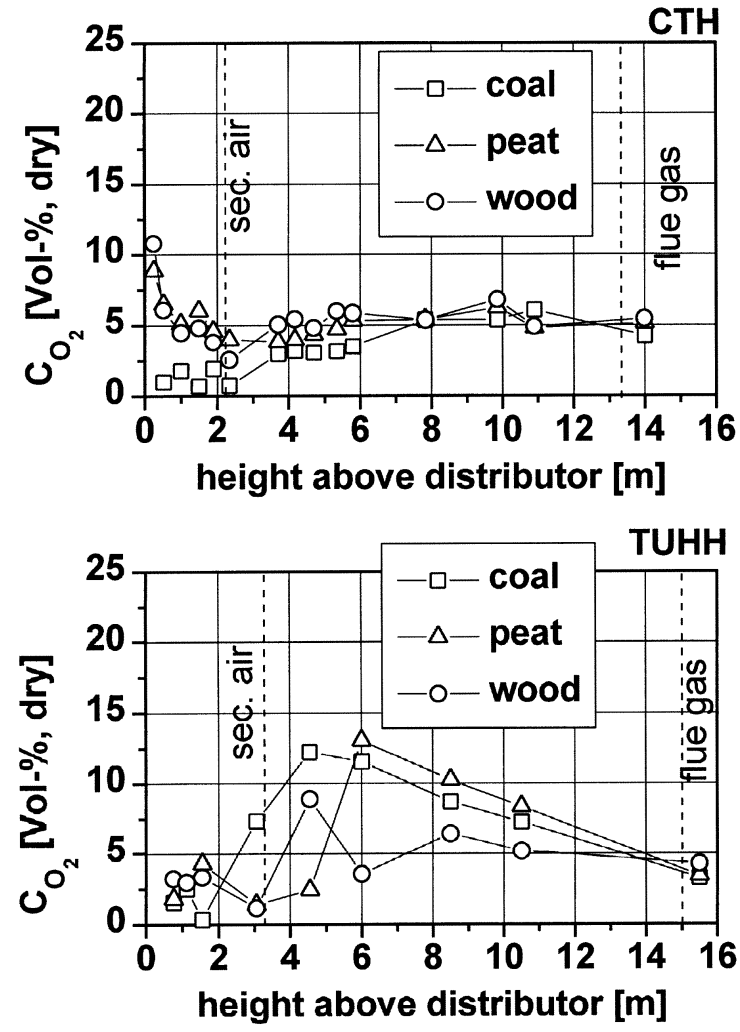

Figure 4 Comparison of axial $\mathrm{O}_{2}$ concentration profiles in the combustors of TUHH and CTH for three different fuels. For operating parameters, see Table 1

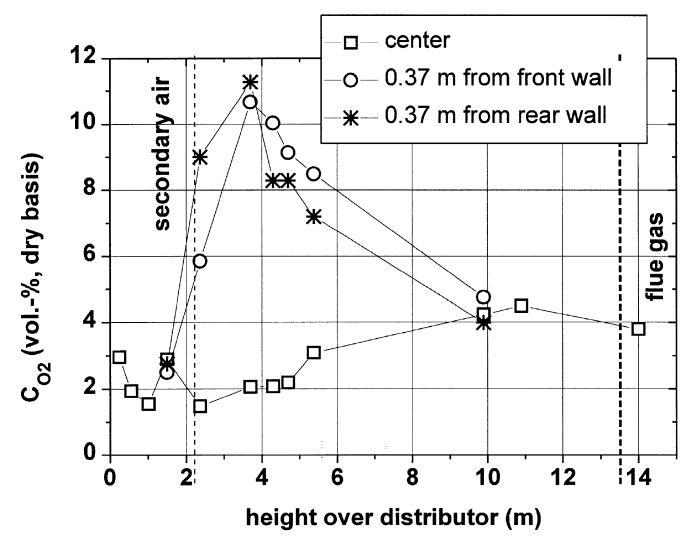

Figure 5 Axial oxygen profiles in the $\mathrm{CTH}$ boiler at different locations during coal combustion (figure taken from $\AA^{\circ}$ and $^{6}$ )

higher char holdup can be expected, which may lead to higher $\mathrm{CO}$ concentrations in the bottom zone of the Chalmers combustor. Table 5 shows a comparison of the average char mass fraction, $\xi_{\text {average }}(\%)$, and the local char mass fraction in the bottom section, $\xi_{\text {bottom }}(\%)$, in the combustors of TUHH and CTH. The local char mass fraction in the bottom bed is higher in the $\mathrm{CTH}$ furnace for all fuels investigated.

Another reason for the higher values of $\mathrm{CO}$ concentration in the bottom region of the $\mathrm{CTH}$ combustor might be the different flow regimes in the bottom part of the units, which result from the difference in bed diameters. It is believed that the bottom part of the CFB boiler generally behaves like
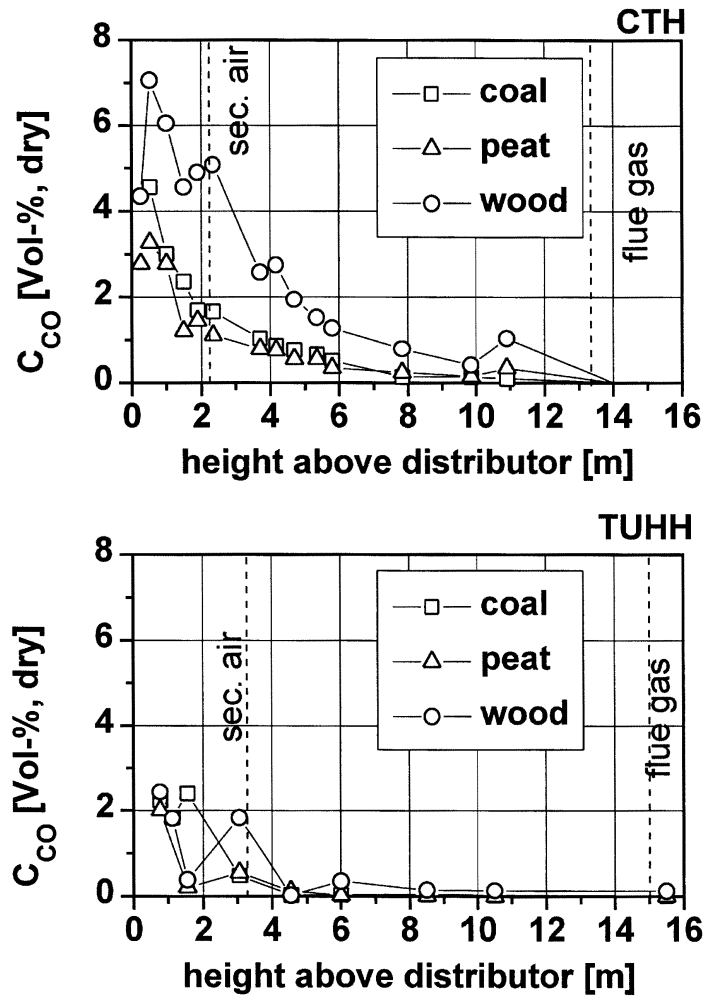

Figure 6 Comparison of axial $\mathrm{CO}$ concentration profiles in the combustors of TUHH and CTH for three different fuels. For operating parameters, see Table 1
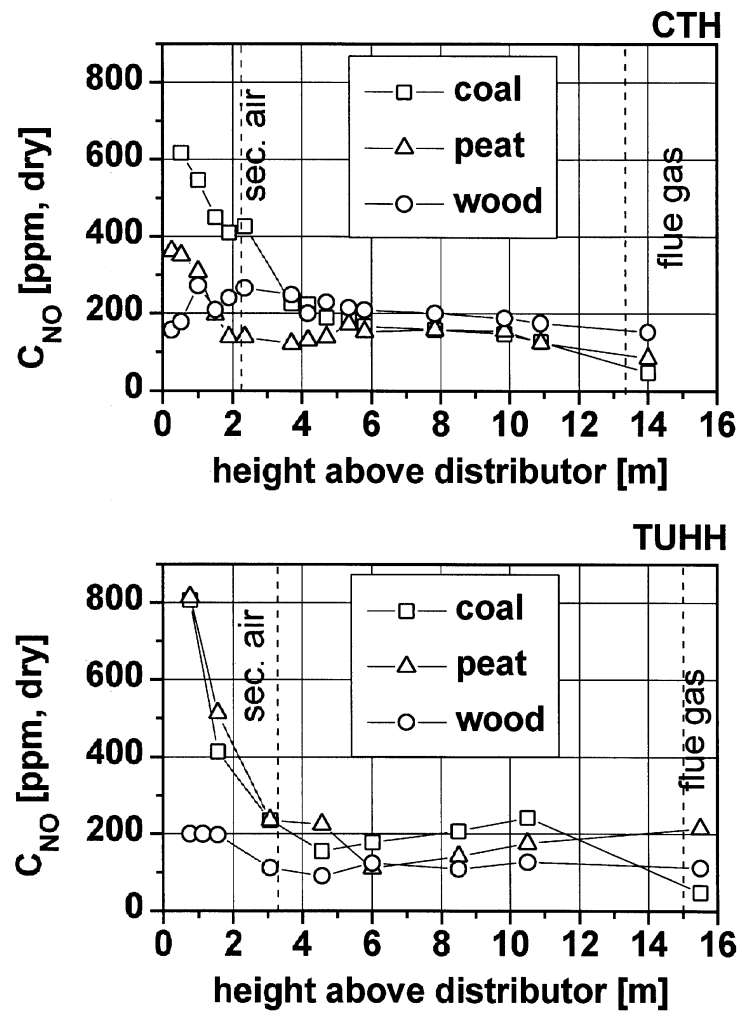

Figure 7 Comparison of axial NO concentration profiles in the combustors of TUHH and CTH for three different fuels. For operating parameters, see Table 1 

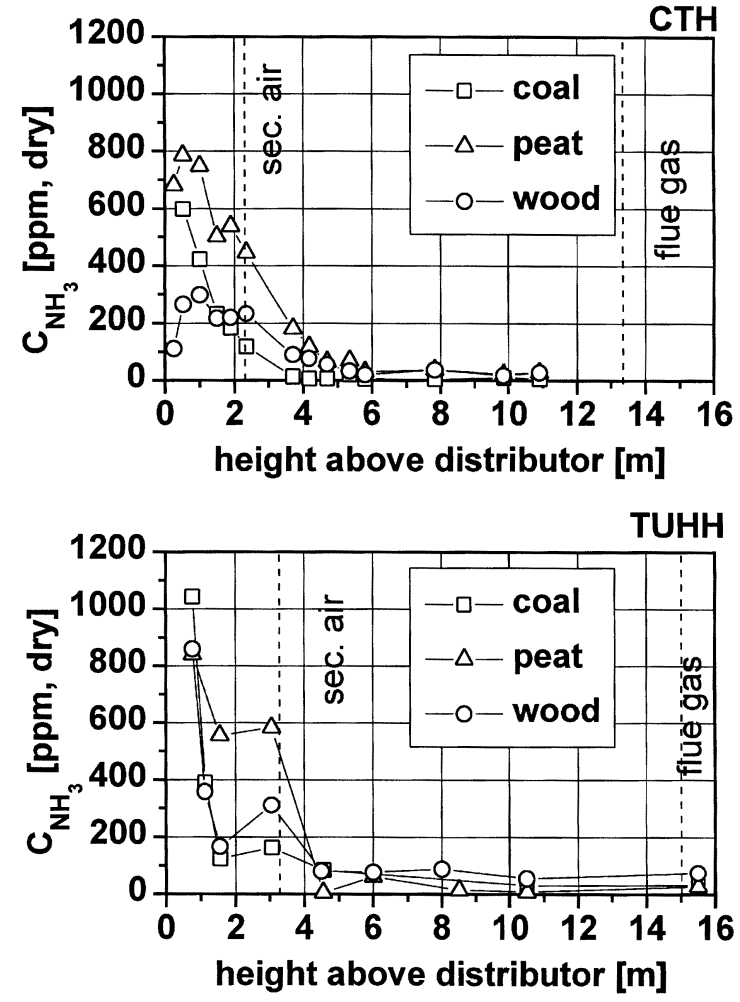

Figure 8 Comparison of axial $\mathrm{NH}_{3}$ concentration profiles in the combustors of TUHH and CTH for three different fuels. For operating parameters, see Table 1

a bubbling bed ${ }^{18,19}$. Matsen ${ }^{20}$ reported that laboratory- and pilot-scale equipment usually show slug-flow behaviour, whereas large fluidized beds are generally not in slug flow. Speculating, on the basis of these differences in flow pattern, one would assume that the gas concentration measurements in the TUHH facility are much more influenced by the bypassing bubble gas than those of the $\mathrm{CTH}$ boiler, where the measurements are also influenced by the gas concentrations in the suspension phase. Since the quickly bypassing bubbles may be characterized by low $\mathrm{CO}$ concentrations, the measured $\mathrm{CO}$ concentration in the bottom region of the TUHH combustor might be lower. The bypassing gas through the bubbles and its effect on the interpretation of concentration measurements with suction probes have been investigated by Lyngfelt et $a l^{21}$, who developed a correction correlation for the bypass flow.

Downstream of the secondary-air injection the $\mathrm{CO}$ concentrations decrease rapidly in both combustors due to the oxidizing conditions in the upper part of the riser. In the case of wood, a distinct second CO maximum is observed at the height of the secondary-air injection in both combustors. This second maximum is stronger in the TUHH facility.

The CO emissions of the CTH boiler, measured downstream of the cylone exit duct, are lower for all of the fuels
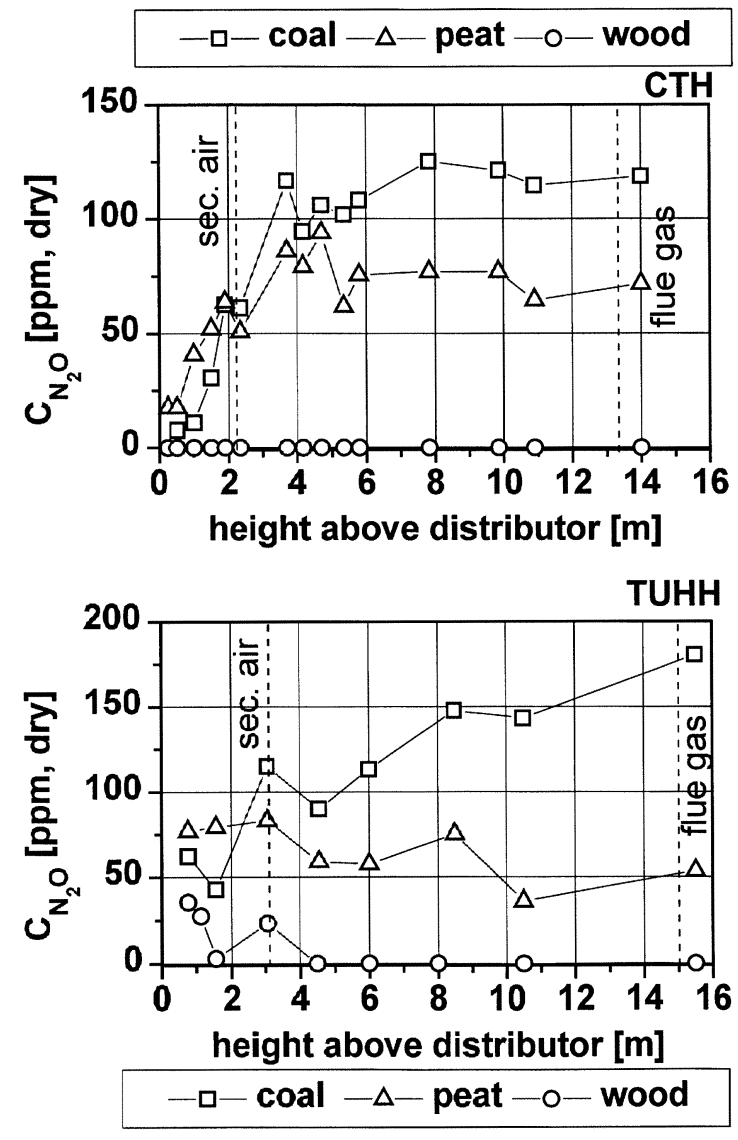

Figure 9 Comparison of axial $\mathrm{N}_{2} \mathrm{O}$ concentration profiles in the combustors of TUHH and CTH for three different fuels. For operating parameters, see Table 1

investigated than those of the TUHH combustor, where the emissions were measured after the secondary cyclone. Since it is known that a significant reduction of $\mathrm{CO}$ may occur in cyclones, a possible reason for the lower $\mathrm{CO}$ emission values of the CTH boiler is the longer gas residence time in the cyclone. In fact, the residence time of the flue gas in the Chalmers cyclone and its inlet duct is $1.2 \mathrm{~s}$ and thus more than twice that of the flue gas in the primary and secondary cyclones of the TUHH facility, which is $0.43 \mathrm{~s}$ only. A further reason is the difference in temperatures inside the cyclones: the temperatures in the primary and secondary cyclones of the TUHH test rig $\left(820^{\circ} \mathrm{C}\right.$ and $750^{\circ} \mathrm{C}$, respectively) are much lower than the temperature of $850^{\circ} \mathrm{C}$ inside the cyclone of the Chalmers boiler. Therefore, the temperature-dependent reaction rate of $\mathrm{CO}$ oxidation inside the cyclones of TUHH is lower.

Figure 7 shows a comparison of the axial NO profiles. In both combustors the formation of NO takes place mainly in the bottom part of the combustion chamber below the fuel feed point, where most of the char burns and where the volatiles are released and oxidized. With increasing height

Table 5 Comparison of the average char mass fraction, $\xi_{\text {average }}(\%)$, and the local char mass fraction in the bottom section, $\xi_{\text {bottom }}(\%)$, in the combustors at TUHH and CTH

\begin{tabular}{lllllll}
\hline Unit & TUHH & & & CTH & & \\
\cline { 2 - 7 } Fuel & Coal & Peat & Wood & Coal & Peat & Wood \\
\hline$\xi_{\text {average }}$ & 1.86 & 0.51 & 0.51 & 1.8 & 0.28 & 0.145 \\
$\xi_{\text {bottom }}$ & 2.56 & 0.26 & 0.05 & 3.1 & 0.52 & 0.1 \\
\hline
\end{tabular}


above the distributor, a rapid decrease of NO is observed in both combustors. Particularly during coal and peat combustion, the NO concentrations in the bottom of the combustion chamber of the TUHH facility are higher. Since NO is reduced by $\mathrm{CO}$ to form $\mathrm{N}_{2}$ and $\mathrm{CO}_{2}$, a lower amount of $\mathrm{CO}$ in the bottom section causes less reduction ${ }^{16}$. As already mentioned above, the measured $\mathrm{CO}$ values are lower in the bottom part of the TUHH combustor and this is the reason for the higher NO concentrations. Beyond the secondary-air injection, the NO profiles of the CTH boiler are steadily decreasing for all of the fuels, whereas during peat and coal combustion in the TUHH combustor a slight increase between 6 and $10 \mathrm{~m}$ above the distributor is observed. The reason for this behaviour may lie in the effect of preparing of the fuel particles by comminution, which leads to an entrainment of fine particles from the bottom region by the fluidization gas into the upper dilute region, where they burn and contribute to the formation of new NO.

Whereas the NO emissions of coal and wood combustion are roughly the same in both combustors, during peat combustion in the TUHH combustor a slightly higher NO emission value is measured.

The formation of ammonia, which is strongly related to the volatile release and volatile combustion, takes place mainly in the bottom section of the riser in both combustors for all fuels investigated (Figure 8). Above the secondaryair injection level the ammonia reduction is almost completed and only low concentration values are measured in the upper part of the combustors. Similar to the CO profiles, the ammonia profiles also show second maxima during wood and peat combustion at the secondary-air injection level, which are stronger in the TUHH circulating fluidized bed combustor. Ammonia is still measured in the flue gas of the TUHH test rig; however, the reason for this is not clear.

In Figure 9 the $\mathrm{N}_{2} \mathrm{O}$ profiles are depicted for both combustors. Neither in the flue gas nor in the combustion chamber of the Chalmers boiler was any $\mathrm{N}_{2} \mathrm{O}$ measured during wood combustion. Except for the bottom region, no $\mathrm{N}_{2} \mathrm{O}$ was measured in the TUHH combustor either in this case.

The $\mathrm{N}_{2} \mathrm{O}$ values measured in the bottom region of the TUHH facility are probably caused by the cross-sensitivity of the $\mathrm{N}_{2} \mathrm{O}$ NDIR analyser with $\mathrm{CO}_{2}$ and not by the combustion process of wood itself. Because of the large wood particles, fluctuations of the time-dependent $\mathrm{CO}_{2}$ concentration signal occurred particularly in the bottom zone, which may lead to unexpected $\mathrm{N}_{2} \mathrm{O}$ values due to the cross-sensitivity of the analyser.

For peat and coal both combustors show a similar behaviour: in the bottom part a strong $\mathrm{N}_{2} \mathrm{O}$ formation can be observed for both fuels. Whereas for coal the increase of the measured $\mathrm{N}_{2} \mathrm{O}$ concentrations continues in the upper part of the riser, for peat a stronger reduction and a new decrease of the concentration are observed in the upper part of the combustors. The $\mathrm{N}_{2} \mathrm{O}$ concentrations in the flue gas are about the same for the peat case in both units. During coal combustion slightly higher $\mathrm{N}_{2} \mathrm{O}$ emissions are measured in the TUHH combustor.

\section{CONCLUSIONS}

A comparison of the axial profiles of the concentrations of the gaseous species $\mathrm{O}_{2}, \mathrm{CO}, \mathrm{NO}, \mathrm{N}_{2} \mathrm{O}$ and $\mathrm{NH}_{3}$ along the riser height, obtained during combustion of wood, peat and coal, shows fair agreement between a small-scale and a large-scale circulating fluidized bed combustor when the units are operated under conditions of both hydrodynamical and chemical similarity. This indicates that lab-scale combustors of suitable dimensions may indeed be a valuable tool for the investigation of combustion phenomena, if attention is paid to this hydrodynamical and chemical similarity. However, some significant deviations of the profiles can be recognized, too. These deviations are caused by three-dimensional effects in the large-scale combustor and by differences in particle sizes in the fuel feed. They indicate the limitations of small-scale experiments. The axial oxygen concentration profiles are strongly influenced by the incomplete penetration of secondary air into the large-scale combustor. For $\mathrm{CO}$, the mixing effects in the bottom zone, the coarser fuel particles and the different dimensions and operating temperatures of the primary cyclones cause differences of the axial concentration profiles and emission values. With respect to $\mathrm{NO}, \mathrm{NH}_{3}$ and $\mathrm{N}_{2} \mathrm{O}$ it can be concluded that the axial concentration profiles of both combustors have basically the same shape for the fuels investigated.

\section{REFERENCES}

1 Lundqvist, R., Basak, A. K. and Smedley, J., in Proc. 11th Int. Conf. Fluidized Bed Combustion, ed. E. J. Anthony. ASME, New York, 1991, pp. 131-138.

2 Leckner, B., in Proc. 26th Int. Symp. on Combustion. The Combustion Institute, 1996, pp. 3231-3241.

3 Moe, T. A., Mann, M. D., Henderson, K. A. and Hajicek, R. D., in Proc. 4th Int. Conf. on CFB, ed. A. A. Avidan. USA, 1993, pp. 91-97.

4 Delebarre, A., Brunello, S. and Queva, T., in Proc 11th. Int. Conf. on Fluidized Bed Combustion, ed. E. J. Anthony. ASME, New York, 1991, pp. 151-156.

5 Legros, R., Brereton, C. M. H., Lim, C. J., Li, H., Grace, J. R. and Anthony, E. J., in Proc. 10th Int. Conf. Fluidized Bed Combustion, ed. A. M. Manaker. ASME, New York, 1989, pp. 661-666.

6 Amand, L. E., Ph.D. thesis, Chalmers University of Technology, 1994.

7 Glicksman, L. R., Hyre, M. and Woloshun, K., Powder Technol., 1993, 77, 177.

8 Horio, M., Ishii, H., Kobukai, Y. and Yamanishi, N., J. Chem. Eng. Jpn, 1989, 22(6), 587.

9 Westphalen, D. and Glicksman, L. R., in Proc. 4th Int. Conf. on Circulating Fluidized Bed, ed. A. A. Avidan. USA, 1993, pp. 436-441.

10 Horio, M., Takada, M., Ishida, M. and Tanaka, N., in Proc. 5th Int. Conf. on Fluidization, eds K. Østergaard and A. Sørensen. Engineering Foundation, New York, 1986, pp. $151-158$.

11 Katayama, H., Tatebayashi, J., Ogiyama, K., Takada, T., Yano, K. and Yutani, S., in Proc. 7th Int. Conf. Fluidized Bed Combustion, ed. N.N. US Department of Energy, Morgantown, WV, 1983, pp. 265-274.

12 Åmand, L. E. and Leckner, B., in Proc. 24th Int. Symp. on Combustion. The Combustion Institute, 1992, pp. 14071414.

13 Werther, J., Ogada, T. and Philippek, C., in Proc. 13th Int Conf. Fluidized Bed Combustion, ed. K. J. Heinschel. ASME, New York, 1995, pp. 951-962.

14 Åmand, L. E., Leckner, B. and Andersson, S., Energy and Fuels, 1991, 5, 815.

15 Thunmann, H. and Leckner, B., in Proc. 4th European Conference on Industrial Furnaces and Boilers, eds. A. Reis, J. Ward, R. Collin and W. Leuckel. INFUB, Portugal, 1997, pp. 205-218.

16 Johnsson, J. E., Fuel, 1994, 73(9), 1398. 
17 Gohla, M., Reimer, H., Neidel, W. and Shimizu, T., in VDIBerichte 1314. VDI Verlag, Düsseldorf, 1997, pp. 327-340.

18 Svensson, A., Johnsson, F. and Leckner, B., Powder Technol., 1996, 86, 299.

19 Werther, J. and Wein, J., AIChE Symp. Ser., 1994, 90, 31.

20 Matsen, J. M., Powder Technol., 1996, 88, 237.

21 Lyngfeldt, A., Åmand, L.-E. and Leckner, B., in Proc. 26th Int. Symp. on Combustion. The Combustion Institute, 1996, pp 3252-3259.

\section{NOMENCLATURE}

$c_{i} \quad$ concentration of species $i(\mathrm{vo} \%)$

$\bar{c}_{\mathrm{v}} \quad$ average solid concentration in the combustion chamber

$D \quad$ diameter of the combustion chamber $(\mathrm{m})$

$d \quad$ particle diameter $(\mathrm{mm})$

$g \quad$ acceleration due to gravity $\left(\mathrm{m}^{2} \mathrm{~s}^{-1}\right)$

$G_{\mathrm{s}} \quad$ solids net flux, related to the cross-section of the combustion chamber $\left(\mathrm{kg} \mathrm{m}^{-2} \mathrm{~s}^{-1}\right)$

$H$ total height of the combustion chamber (m)

$L \quad$ characteristic dimension of the bed $(\mathrm{m})$

$\Delta p \quad$ pressure drop along the height of the combustion chamber $(\mathrm{kPa})$

$u \quad$ superficial gas velocity $\left(\mathrm{m} \mathrm{s}^{-1}\right)$

\section{Greek symbols}

$\theta$ temperature in the combustion chamber $\left({ }^{\circ} \mathrm{C}\right)$

$\lambda \quad$ excess air ratio

$\mu \quad$ dynamic viscosity of the flue gas (Pa s)

$\xi \quad$ char mass fraction $(\%)$

$\rho \quad$ density $\left(\mathrm{kg} \mathrm{m}^{-3}\right)$

$\Phi \quad$ sphericity of the particle

\section{Subscripts}

CTH full-scale boiler of the Chalmers University of Technology

TUHH experimental facility at the Technical University Hamburg-Harburg

$\begin{array}{ll}\mathrm{g} & \text { gas } \\ \mathrm{p} & \text { solid }\end{array}$ 